REGARDS

SUR L'ECONOMIE ALLEMANDE

BULLETIN ECONOMIQUE DU CRAC

\section{Regards sur l'économie allemande}

Bulletin économique du CIRAC

$80 \mid 2007$

Varia

\title{
Jeux vidéo : un marché en forte croissance
}

\section{Isabelle Bourgeois}

\section{OpenEdition}

Journals

Édition électronique

URL : http://journals.openedition.org/rea/714

DOI : $10.4000 /$ rea. 714

ISBN : 978-2-8218-0856-0

ISSN : 1965-0787

Éditeur

CIRAC

Édition imprimée

Date de publication : 1 mars 2007

Pagination : 38

ISSN : 1156-8992

Référence électronique

Isabelle Bourgeois, " Jeux vidéo : un marché en forte croissance », Regards sur l'économie allemande [En ligne], 80 | mars 2007, document 4, mis en ligne le 01 mars 2009, consulté le 15 septembre 2020 URL : http://journals.openedition.org/rea/714

Ce document a été généré automatiquement le 15 septembre 2020

(C) CIRAC 


\title{
Jeux vidéo : un marché en forte croissance
}

\author{
Isabelle Bourgeois
}

En 2006, le marché allemand des jeux vidéo et PC a réalisé un CA de 1,13 milliard $€$, ce qui représente une croissance de $+7,4 \%$, annonce la fédération du secteur, la Bundesverband Interaktive Unterhaltungssoftware (BIU), estimant que ni la canicule ni le Mondial de football ne sont parvenus à entamer l'engouement des Allemands pour ce type de loisirs. Le secteur connaît pourtant d'habitude de fortes fluctuations saisonnières, l'essentiel du CA étant réalisé durant les mois d'hiver. Si le segment des jeux sur ordinateur $(473,4$ millions $€$ ) a stagné $(+0,4 \%)$, celui des jeux vidéo, le plus important (CA : 652,6 millions $€$ ), a été particulièrement dynamique (+13\%) malgré le changement de génération intervenu au niveau des consoles. Il a été tiré principalement par les logiciels destinés aux portables en tout genre, un segment en hausse de $+58 \%$ (CA : 190 millions $€$ ). La BIU se montre très optimiste pour $2007:$ le lancement de la Playstation 3 de Sony, prévu en Europe le 23 mars, devrait doper les ventes.

\section{INDEX}

Mots-clés : croissance, loisir, marché 